\title{
ASPECTOS DA ANATOMIA FOLIAR DE Stevia rebaudiana (BERT.) Bertoni (COMPOSITAE)
}

Thereza Grassiolli, Maria Helena Cechella Achutti e Amélia Moema Veiga Lopes

Departamento de Biologia. Centro de Ciências Naturais e Exatas.UFSM. Santa Maria, RS.

RESUMO

Foram estudadas folhas de plantas cultivadas, vivas ou fi xadas, em cortes transversais e paradérmicos. Fez-se a determinação da ārea ocupada pelas células epidérmicas, estōmatos e tricomas, se gundo método estereológico. Para essa determinação e o estudo da ve nação, utilizaram-se folhas inteiras, clarificadas. A estrutura das folhas é dorsiventral. Os estomatos são anomociticos. Os tricomas são dos tipos cōnico, filiforme, glandular bisseriado. A venação é acrōdroma. Plexos de terminaçoes de nervuras se dirigem para o àpi ce dos dentes da margem serreada, participando da formação de hida tódios. Os feixes vasculares são colaterais, ocorrendo diferencia ção de fibras do floema. Os feixes vasculares das nervuras de ordem mais alta apresentam bainha parenquimática. Canais secretores esqui zógenos, opostos ao protoxilema, acompanham as nervuras primárias.

SUMMARY

GRASSIOLLI, T.; ACHUTTI, M.H.C. and LOPES, A.M.V., 1985. Leaf structure of Stevia rebaudiana (Bert.) Bertoni (Compositae). Ciência e Natura, 7: $129-144$.

Leaves of cultivated plants, alive or fixed, in paradermal and cross sections were studied. The determination of occupied area by epidermal cells, stomata and trichomes according to the stereological method was done. For this determination and the study of venation, whole clarified leaves were used. The structure of leaves is dorsi ventral. The stomata are anomocytic. The trichomes area of the conical, filiform and glandular biseriate types. The venation is acrodromous. The vascular bundles have a collateral arrangement. Floem fibers are present. The minor veins have paranchymatic bundle sheat. Hydathodes occur at the apices of serrations on the margins of leaves. Schizoge nous secretory canals, opposed to protoxylem, accompany the primary veins.

INTRODUÇĀO

Stevia rebaudiana (Bert.) Bertoni é Compositae, nativa da região limitrofe entre o Brasil e o Paraguai. 0 interesse pelo cul tivo dessa planta no Brasil vem aumentando cada vez mais nos ūltimos 
anos (13). Sua importância decorre, principalmente, da presença de esteviosideo que possui propriedades adoçantes.

FELIPPE (2) e SAKAGUCHI \& KAN (13) apresentam revisão dos trabalhos publicados a respeito de $S$. rebaudiana. São estudos de fi siologia, química, farmacologia, cultivo, cultura de tecido e taxo nomia.

Com o presente trabalho, visamos a estudar aspectos da es trutura foliar de $S$. rebaudiana, tendo como objetivo conhecer sua organização.

MATERIAL E METODOS

Foram estudados exemplares cultivados no Departamento de Fitotecnia da Universidade Federal de Santa Maria, Rio Grande do Sul e em Capão Bonito, Vale da Ribeira, Estado de São Paulo. Foram us a das folhas jovens e adultas, vivas ou fixadas. Os fixadores usados foram FAA 50, FPA (8) e álcool etîlico a 70\% (7). Foram feitas lâmi nas temporārias, com cortes a mão livre, utilizando-se, como coran te, vermelho neutro (8). Para a elaboração das lâminas permanentes, seguiu-se a técnica usual de inclusão em parafina, usando-se o pro cesso de dupla coloração safranina - "fas-green" (8). Para identifi cação da natureza dos constituintes celulares, foram efetuados tes tes histoquímicos, utilizando-se Lugol, Sudan IV e floroglucina em meio ăcido (14). Para o estudo da venação, as folhas foram diafani zadas, segundo técnica indicada por FOSTER (4). A determinação da ārea ocupada pelas cēlulas epidērmicas, estōmatos e tricomas, foi obtida pelo método estereológico da fração de pontos (6), em folhas inteiras, clarificadas pela água sanitāria comercial. Aspectos da morfologia, incluindo padrão de venação, foram descritos segundo o método proposto por HICKEY (5). Para a descrição da estrutura dos tricomas, tomou-se por base o estudo de tricomas de compositae rea lizado por RAMAYYA (11). Os desenhos foram feitos ao microscōpio ōti co, com o auxîlio da cámara clara. O aspecto geral da venação foi obtido atravēs da projeção de lâmina em um anteparo.

\section{RESULTADOS}

As folhas de Stevia rebaudiana são simētricas, elīpticas, com margens convexas inteiras, na base, e serreadas nas porçoes mé dia e apical. 0 àngulo apical dos dentes é obtuso ou reto. 0 tipo de serreado é convexo, com espaciação comumente regular e seriação simples. O àpice da lâmina è agudo, a base é aguda, atenuada. A tex tura è membranácea. A posição das glāndulas (tricomas glandulares) é laminar. O pecīolo está ausente ou é muito curto com a base alar gada.

Epiderme - A lâmina foliar adulta, de estrutura nitidamente 
dorsiventral, ē revestida de epiderme unisseriada, provida de trico mas tectores e glandulares. Os tricomas glandulares se alojam em concavidades da epiderme, o que confere a mesma aspecto ondulado.

Em vista frontal, a epiderme das superficies adaxial e aba xial é formada por cēlulas com tamanho e forma variados. As paredes celulares são delgadas, sendo as anticlinais onduladas (Figuras 1 $a, b)$. Em corte transversal, predomina o diāmetro periclinal das cé lulas sobre o diāmetro anticlinal. As células da face adaxial são maiores que as da abaxial. A epiderme é revestida da cutícula fina com estrias epicuticulares (Figuras 1 c,d).

Estômatos - Os estômatos estão distribuídos irregularmen te em ambas as faces, podendo ocorrer estomatos geminados (Figura 1 b). São mais elevados do que as cēlulas epidērmicas. Na face aba xial, são mais elevados e numerosos do que na face adaxial (Figura 1 c,d). As determinações histométricas, apresentadas na Tabela I, mos tram a relação da área ocupada pelas cēlulas epidérmicas, estômatos e tricomas, nas faces adaxial e abaxial da lâmina foliar adulta.

Na sequência de Figuras $2 a-f$, correspondentes à epiderme de folhas jovens, estão representadas fases do desenvolvimento dos estōmatos. As cēlulas da protoderme, em geral, estão pouco diferen ciadas. Em vista frontal, sua forma é geralmente poligonal, tenden do para arredondada. O citoplasma è denso e o nūcleo é grande em ré lação ao volume da célula. Na Figura 2 a, vē-se cēlula em inīcio de divisão que conduzirā à formação de duas cểlulas desiguais em forma e tamanho. A Figura $2 b$ mostra uma célula pequena, triangular e uma maior. Ambas resultaram de uma divisão irregular semelhante à indi cada na Figura 2a. A célula triangular pequena é a cêlula-mãe do es tômato. Esta célula divide-se, formando as duas células oclusivas: na Figura $2 c$, vê-se o início da divisão e na Figura $2 d$, as duas cé lulas jā estão individualizadas. Nas Figuras 2e,f, aparecem estôma tos em fase final de diferenciação, com nūcleo parietal e vacúolos grandes. As células epidérmicas que circundam as oclusivas não se distinguem das demais pelo aspecto. Os estōmatos são do tipo anomo citico.

Tricomas - Os tricomas são dos seguintes tipos: simples có nico, simples filiforme e glandular bisseriado vesicular.

o simples cōnico é um tricoma não ramificado, unisseria do, pluricelular. o pē é composto, o corpo é unisseriado inteiro, afilado no àpice e formado de sete a dez células. As cēlulas do àpi ce são longas, e as da base têm o diāmetro transversal maior do que - longitudinal. As paredes são espessadas e cutinizadas (Figura lb).

o simples filiforme é um tricoma não ramificado, unisse riado, pluricelular. O pé é simples, o corpo unisseriado inteiro, ar redondado no ápice e formado de quatro a cinco cēlulas com o diāmetro 


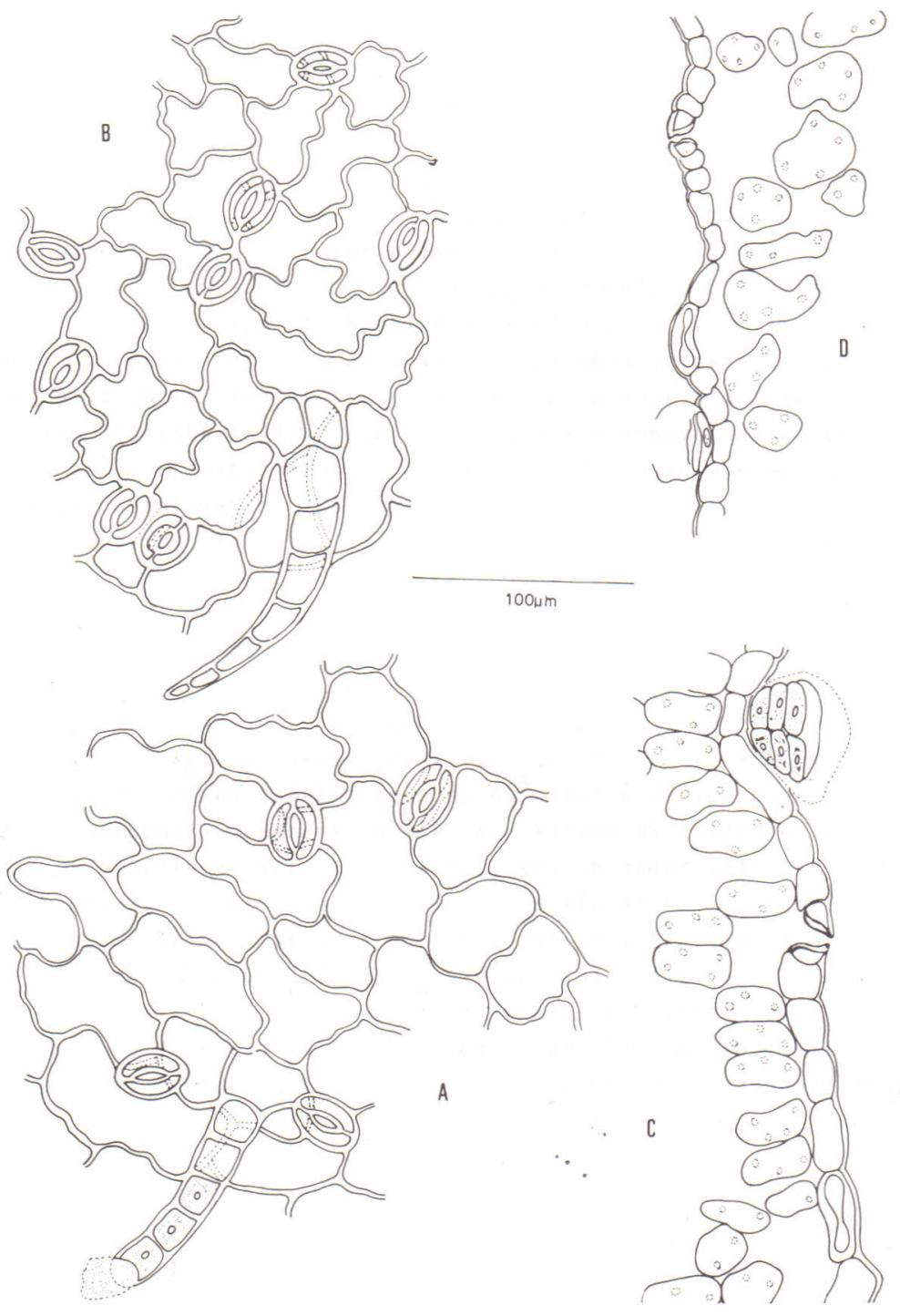

Figura 1. Epiderme Foliar. A - face adaxial em vista frontal, mos trando tricoma simples filiforme. B - face abaxial em vis ta frontal, mostrando tricoma simples cōnico. C - facé adaxial em corte transversal, mostrando tricoma glandular bisseriado. D - face abaxial em corte transversal. 

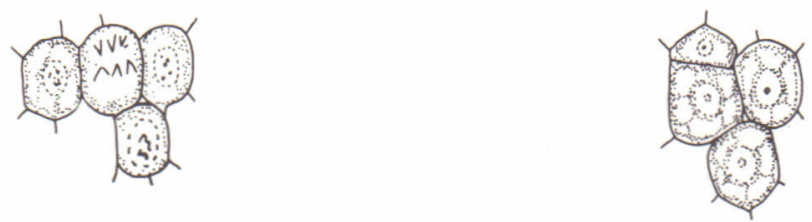

A

B
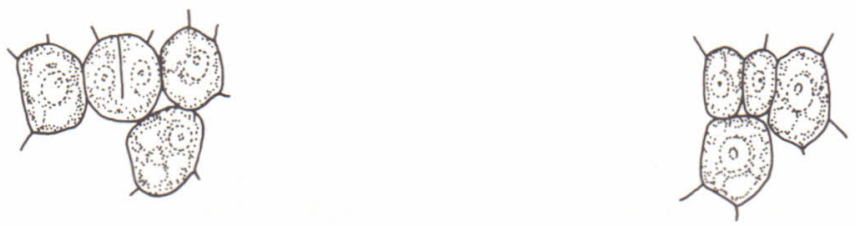

c

D
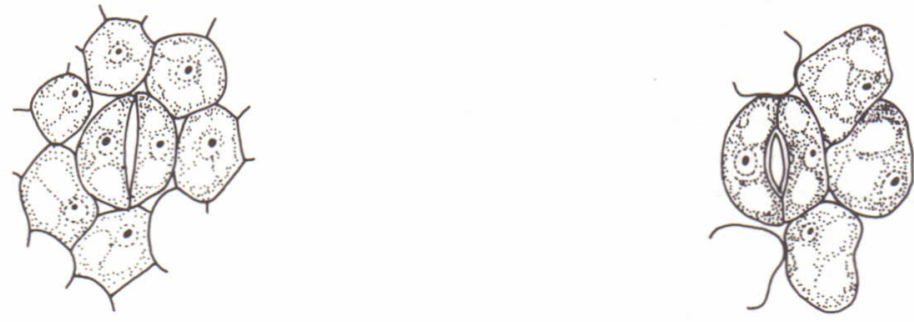

E

Figura 2 A-F - Fase do desenvolvimento de estômatos em epiderme de folhas jovens. 
longitudinal maior do que o transversal. As paredes celulares são delicadas sendo as das células basais cutinizadas. As células termi nais possuem um conteúdo mais denso e a longevidade parece ser me nor em relação às basais. O tricoma filiforme se apresenta curvado em direção à epiderme, ficando o ápice pendente (Figura la).

TABELA I. VALORES DA DETERMINAÇAOO HISTOMETRICA DAS FRAÇOES DE CELU LAS EPIDERMICAS, ESTŌMATOS E TRICOMAS NA LĀMINA FOLIAR DE Stevia rebaudiana.

\begin{tabular}{|c|c|c|c|c|}
\hline Tipo celular & $\begin{array}{l}\text { Valor } \\
\text { mînimo }\end{array}$ & $\begin{array}{l}\text { FACE } \\
\text { Mëdia }\end{array}$ & $\begin{array}{l}\text { ADAXIAL } \\
\text { Valor } \\
\text { mäximo }\end{array}$ & $\begin{array}{l}\text { Desvio } \\
\text { padrão }\end{array}$ \\
\hline Células epidérmicas & 78,0 & 84,3 & 88,0 & 2,79 \\
\hline Estōmatos & 5,0 & 5,9 & 8,0 & 1,37 \\
\hline Tricoma simples cōnico & 0,0 & 1,9 & 3,0 & 1,10 \\
\hline Tricoma simples filiforme & 1,0 & 2,7 & 3,0 & 1,41 \\
\hline \multirow[t]{2}{*}{ Tricoma glandular bisseriado } & 3,0 & 5,2 & 7,0 & 1,22 \\
\hline & \multicolumn{4}{|c|}{ FACE ABAXIAL } \\
\hline Tipo celular & $\begin{array}{l}\text { Valor } \\
\text { minimo }\end{array}$ & Média & $\begin{array}{l}\text { Valor } \\
\text { máximo }\end{array}$ & $\begin{array}{l}\text { Desvio } \\
\text { padrão }\end{array}$ \\
\hline Células epidérmicas & 68,0 & 74,0 & 77,0 & 2,70 \\
\hline Estômatos & 12,0 & 14,9 & 18,0 & 1,72 \\
\hline Tricoma simples cônico & 3,0 & 4,1 & 6,0 & 0,99 \\
\hline Tricoma simples filiforme & 3,0 & 4,1 & 6,0 & 1,10 \\
\hline Tricoma glandular bisseriado & 3,0 & 3,8 & 5,0 & 0,78 \\
\hline
\end{tabular}

O tricoma grandular bisseriado vesicular tem o pé compos to por duas células, o corpo é bisseriado, inteiro com quatro célú las em cada fileira. As células são aproximadamente do mesmo tama nho, com exceção das terminais que são mais longas. As paredes são delicadas, as externas levamente convexas e o citoplasma è denso. Todas as células do corpo são secretoras. A vesỉcula cuticular envol ve uma ou mais camadas celulares terminais (Figura 1c).

Mesofizo - o mesofilo, na folha adulta, é formado por um parênquima assimilador diferenciado em paliçādico lacunoso (Figura 3). O paliçádico está junto à epiderme da face adaxial e o lacuno so, junto à face abaxial. O parênquima paliçādico é formado de duas a três camadas de células. Na primeira camada, as células são alon gadas, compactadas e perpendiculares à epiderme. Os espaços observa dos correspondem às câmaras subestomáticas. A camada mais interna do paliçādico não é tão homogēnea como a externa e tem alguma semelhan ça com o lacunoso. 


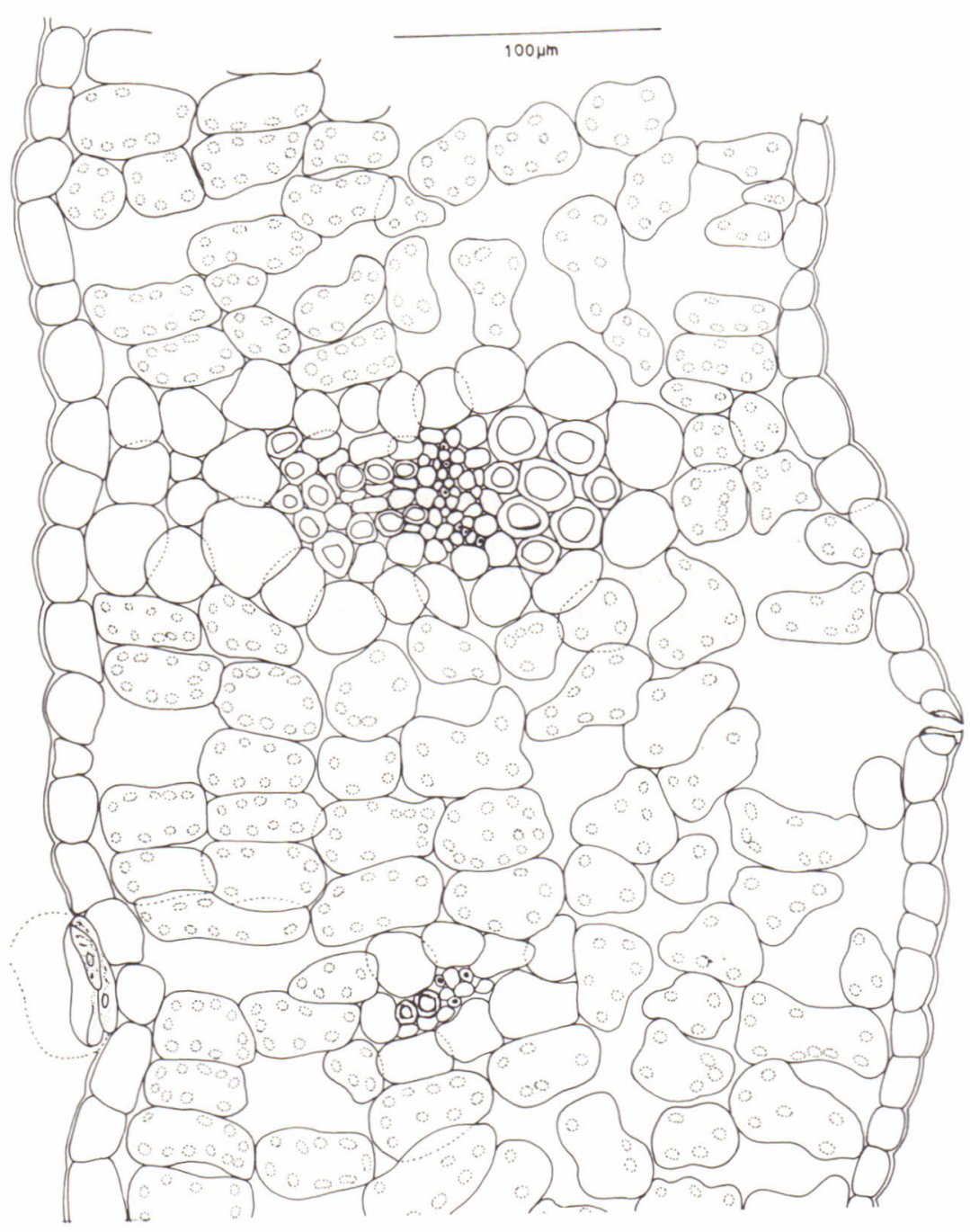

Figura 3. Corte transversal de lâmina foliar, mostrando aspecto do mesófilo e nervuras de pequeno porte. 
0 tecido lacunoso é formado de três a quatro camadas de cēlulas heteromörficas, com espaços intercelulares acentuados e profun das câmaras subestomāticas.

$\mathrm{Na}$ porção inteira da margem da folha, ocorre parênquima pa liçádico logo abaixo da epiderme. Esse parēnquima é formado de uma ou duas camadas de cēlulas muito prōximas umas das outras. Nessa re gião, não foram evidenciados estōmatos (Figura 4a).

$\mathrm{Na}$ porção serreada, no āpice dos dentes, formam-se hidató dios. Após a epiderme, ocorre um parênquima semelhante ao lacunoso, tanto na forma das células como nos espaços intercelulares. Esses espaços, grandes e frequentes, correspondem às câmaras subestomāti cas. Elementos condutores do xilema, pertencentes a plexos de termi nações de nervuras, chegam muito prōximo à epiderme. Muitas vezes, vê-se apenas uma camada de células entre o elemento condutor e a epiderme. Na extremidade livre desses elementos condutores, não ocor re bainha de feixe (Figura 4b).

Veną̧ão - A venação é acródroma, suprabasal com desenvol vimento perfeito (Figura 5a). Laços broquidódromos ocorrem no ápi ce da lâmina. As nervuras primárias (mediana e laterais) são de tá manho moderado, percurso reto ou curvado, ramificado. As nervuras secundārias tēm àngulo de divergēncia agudo moderado. A espessura dessas nervuras é moderada, o percurso curvado de maneira abrupta, sinuoso, ramificado. As ramificações que formam arco unen-se às ner vuras secundārias supra-adjacentes em āngulo reto ou agudo e estão encerradas por arcos secundārios. O ângulo de origem das nervuras terciārias, no lado inferior das secundārias, é reto; no lado supe rior, é agudo ou reto. As nervuras terciārias mostram padrão reticu lado: nervuras terciārias se anastomosam com outras terciārias ou com nervuras secundārias (Figura 5b).

A venação de ordem mais alta forma um retículo no qual não se distinguem ordens de nervuras. Sua trajetōria é predominantemen te ortogonal. As vēnulas são simples, sem ramificaçôes, curvadas, às vezes, lineares, ou ramificadas uma a três vezes por dicotomização. As aréolas são de forma quadrangular, pentagonal ou, ainda poligo nal. Vēnulas atravessam suas arēolas e tambēm se anatomosam em ar cos (Figura 5c). Traqueideos espiralados isolados, aos pares, ou grupos de três ou mais, formam as extremidades livres das termina ções de nervuras (Figura 5d).

$\mathrm{Na}$ margem inteira a venação ūltima è incompleta, com vēnu las terminais livres, ou arqueada. Na porção serreada da margem, as terminações de nervura livres convergem para o āpice dos dentes.

Nervuras primárias - Na base da lâmina foliar, observam-se em corte transversal, trēs feixes vasculares livres, sendo o central ligeiramente maior (Figura 6). Esses feixes são colaterais. 0s elementos 


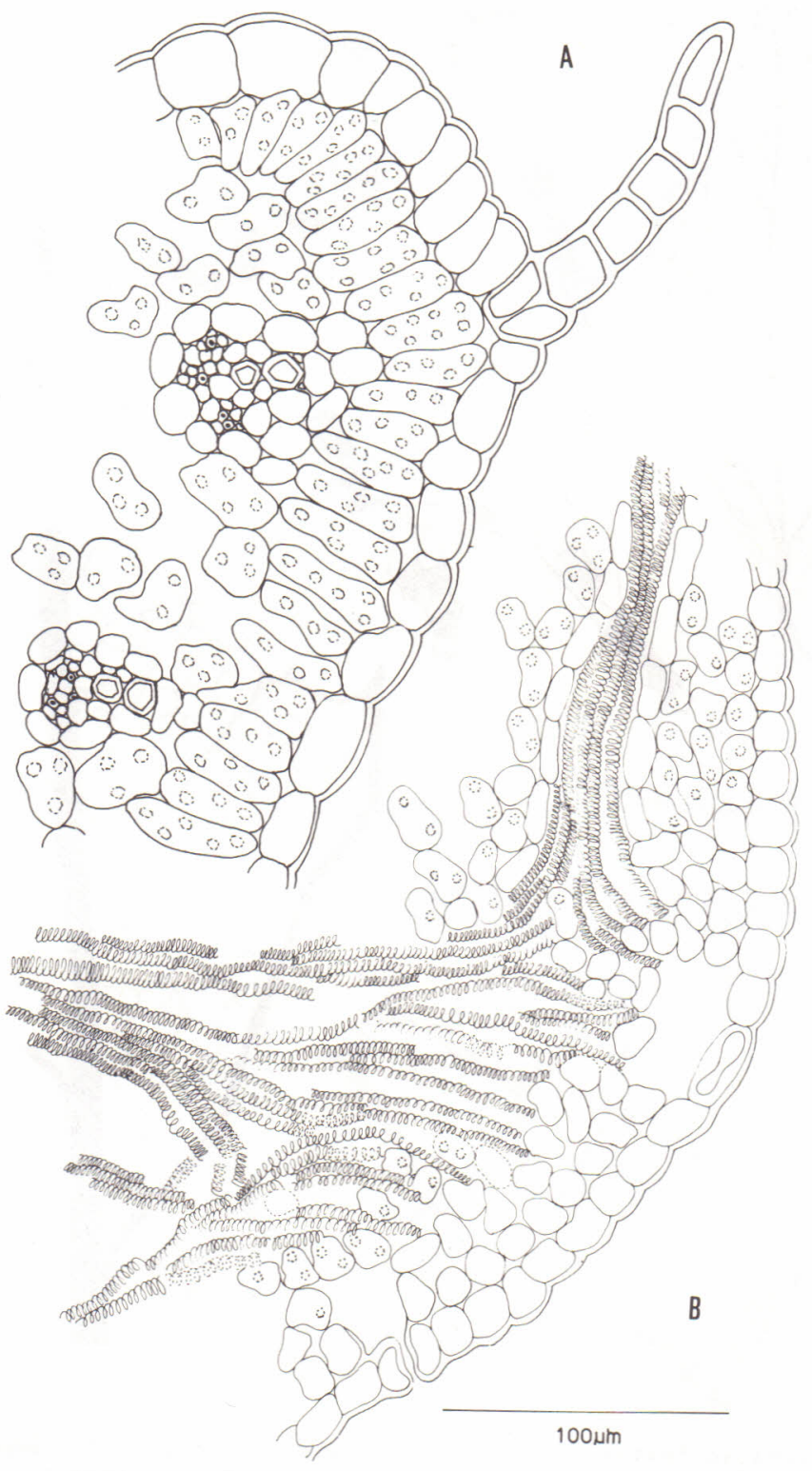

Figura 4. Margem da lâmina foliar. A - corte transversal na porção inteira. A - corte paradérmico na porção serreada. 


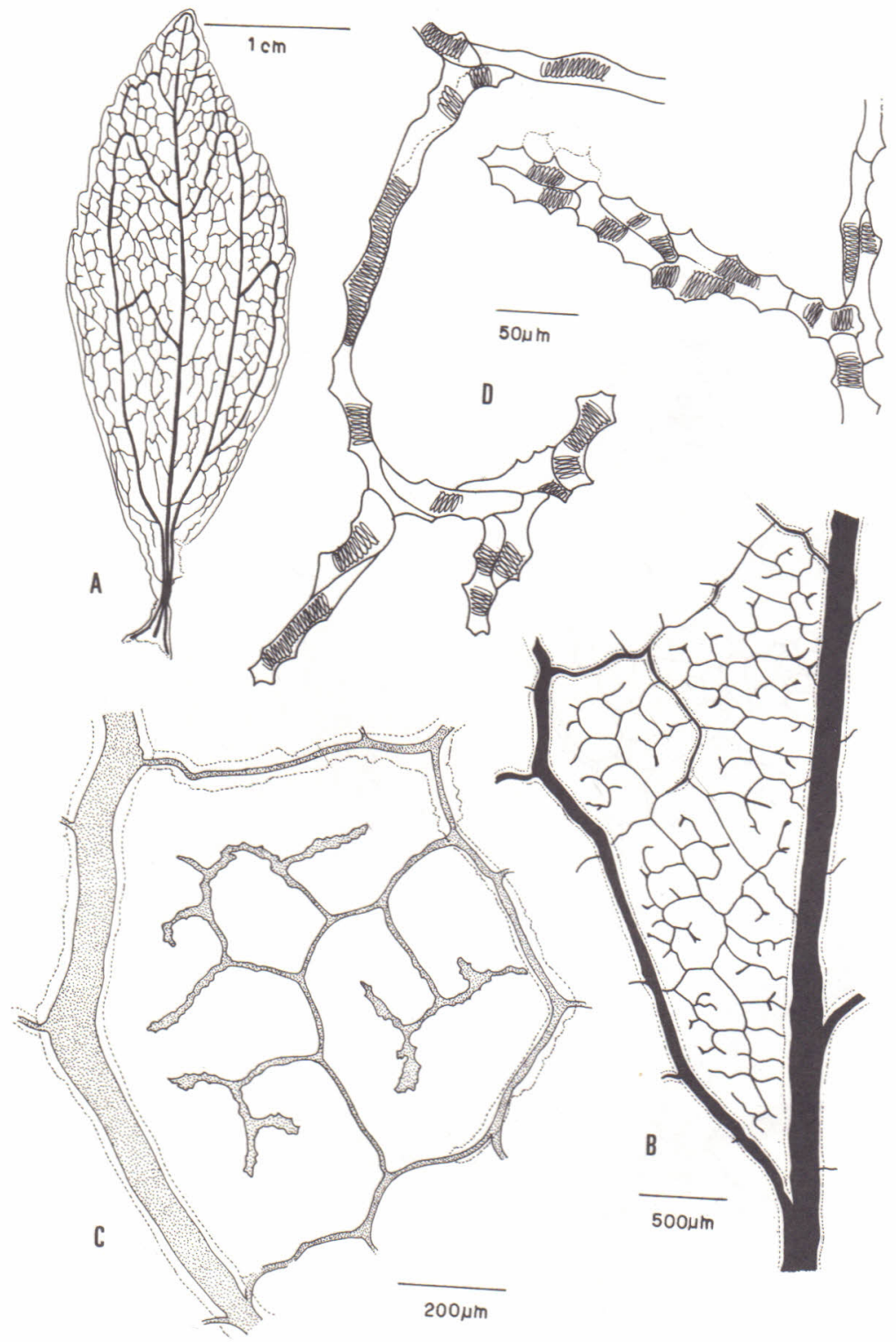

Figura b. Venaçao foliar acrodroma. A - aspecto geral. B - àrea li mitada por uma porção de nervura primária mediana e nervu ra secundāria. C - pormenor, mostrando uma porção de ne $\bar{r}$ vura terciāria e vēnulas. D - terminaçoes de nervuras. As linhas pontilhadas, em $B$ e $C$, representam o esclerên quima que acompanha as nervuras primárias, secundārias $\bar{e}$ terciärias. 


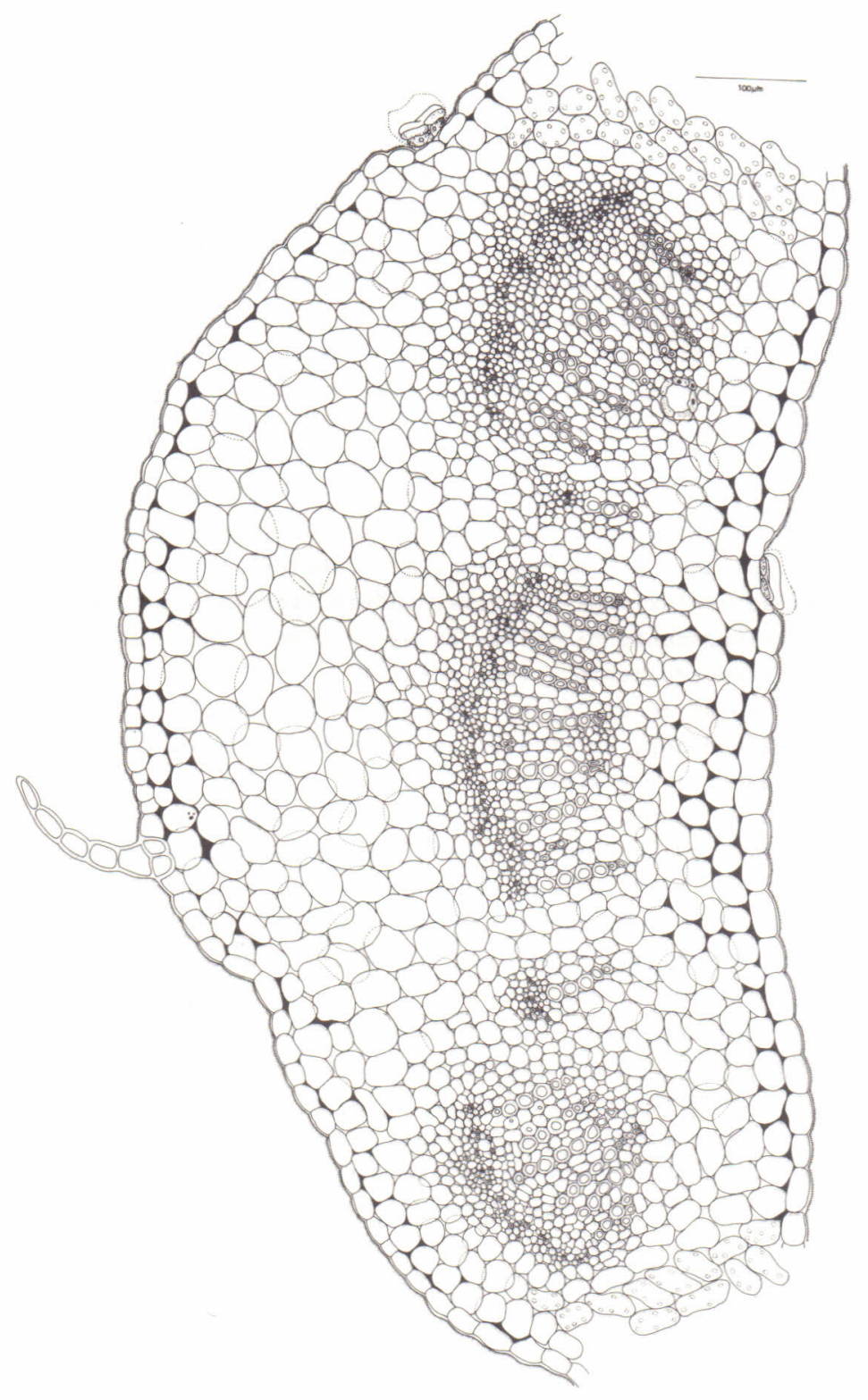

Figura 6. Corte transversal ao nível da base foliar, mostrando canai de secreção em posição oposta ao protoxilema. 
condutores do xilema formam fileiras radiais unisseriadas ou bisse riadas, que se alternam com raios parenquimäticos. Os vasos são ane lados, espiralados ou reticulados com paredes transversais inclina das ou não e perfurações simples. No floema, os tubos crivados e cé lulas companheiras se dispõem em pequenos grupos separados por raios parenquimáticos. Ocorrem fibras do floema, que se lignificam.

Um parênquima fundamental com cēlulas clorofiladas envol ve os feixes vasculares; as cēlulas que limitam com o protofloema contêm amido. Nesse parênquima, os espaços intercelulares são gran des, próximos à face adaxial. Logo abaixo da epiderme, em ambas as faces, ocorre colênquima angular.

A medida que se observa em direção ao āpice da folha, no ta-se que os feixes vasculares laterais se afastam do feixe central, enquanto surge, entre eles, um mesofilo. Formam-se, assim, as trēs nervuras primārias que caracterizam a venação acródroma.

Ao nīvel do terço médio da lâmina foliar, em corte trans versal, o feixe vascular da nervura mediana se assemelha aos da ba se em organização e tamanho (Figura 7). As células parênquimáticas, próximas ao protoxilema e floema, sofrem lignificaçāo que aumenta com o envelhecimento da folha. Um maior nümero de células de colên quima è observado junto à face adaxial.

No àpide da lâmina, em corte transversal, o feixe vascular da nervura mediana, em relação ao terço médio, è bem menor. o parēn quima fundamental se reduz a uma ou duas camadas de cêlulas, fican do o feixe muito próximo ao mesófilo. Fibras do floema estão presen tes. As cêlulas, em posição oposta ao protoxilema, se apresentam ligni ficadas à semelhança do que ocorre com as fibras do floema. Não foi constatada ocorrência de colênquima.

As nervuras primärias laterais se assemelham à nervura me diana em sua organização.

E frequente a ocorrência de canais de secreção esquizóge nos, em posição oposta ao protoxilema, nas nervuras primárias, des de a base até o āpice da folha (Figura 6). Esses canais se dispõem em séries longitudinais descontínuas, são em número de um ou dois por feixe vascular. Observou-se que pode ocorrer a fusão entre dois canais justapostos. Quando ocorre lignificação nas proximidades do protoxilema, inicialmente, ela não atinge o parēnquima que circunda o canal. Com o envelhecimento da folha, apenas as paredes das célu las epiteliais não se apresentam espessadas, lignificadas.

Nervuras de ordem mais alta - Os feixes vasculares, que se encontram no mesofilo propriamente dito, estão circundados por uma bainha de feixe, constitữda de cēlulas parenquimáticas (Figura 3 ). Essas células são comumente alongadas e seu maior diāmetro é parale lo ao eixo longitudinal do feixe. Têm paredes alongadas, cloroplastos 


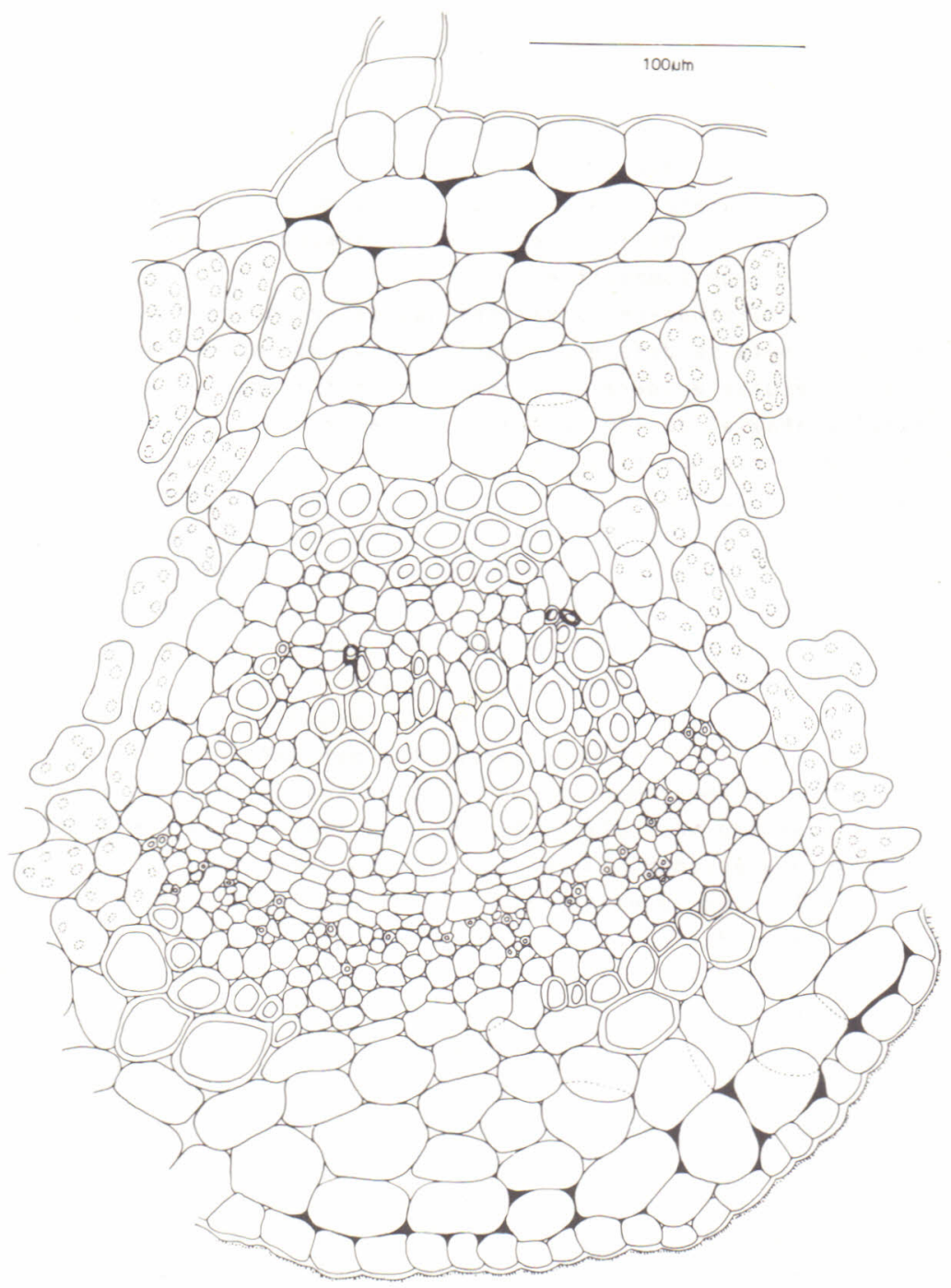

Figura 7. Corte transversal ao nivel do terço médio da nervura mediana. 
pequenos, pouco numerosos e amido. A bainha de feixe pode ou não es tender-se em direção à epiderme. Quando presente, a extensão da ba nha de feixe pode estar em ambos os lados do feixe ou apenas no la do adaxial.

DISCUSSAO

As folhas de $S$. rebaudiana apresentam estrutura dorsiven tral, estômatos anomocíticos, hidatódios nas terminações de nervu ras, feixe vasculares com distinta bainha de parênquima. Segundo METCALFE \& CHALK (1950), esses aspectos anatômicos são de ocorrência comum em folha de Compositae.

Analisando-se os valores das determinações histomētricas (Tabela I) nota-se diferença significativa na relação da ārea ocupa da pelas cēlulas epidérmicas, estômatos e tricomas, entre as faces adaxial e abaxial da lâmina foliar. O valor médio das células epidér micas e dos tricomas glandulares, na face adaxial, é maior do que o da abaxial. O contrārio observa-se em relação aos estōmatos e tri comas cônico e filiforme. O carāter anfiestomático, observado nas folhas de $S$. rebaudiana, é comum na maioria das compositae (10).

No āpice dos dentes das folhas da espēcie em estudo, ocor rem hidatōdios com mais de um estômato (poro). Essa caracteristica é mencionada para compositae por ESAU (1).

Os tricomas das folhas de $S$. rebaudiana exemplificam pa drões estruturais de tricomas propostos por RAMAYYA (12): filiforme (simples filiforme), macroforme (simples cônico) e bisseriado (glan dular bisseriado vesicular). Os tricomas filiforme e cônico são unis seriados como é comum ocorrer com tricomas tectores de compositae (15). O filiforme apresenta as células da porção terminal com pare des mais delicadas e conteüdo mais denso do que as basais. UPHOF \& HUMMEL (16), RAMAYYA (11), fazem referência a tricomas que apresen tam diferença no comportamento das células basais em relação às ap cais. SOLEREDER (15) cita tal ocorrência para Vemonia e Catananche.

0 tricoma glandular bisseriado vesicular é amplamente dis tribuído na familia compositae (15, 9 e 16). Em s. rebaudiana, esse tricoma encontra-se caracteristicamente alojado em concavidades, o que confere à epiderme um aspecto ondulado.

WYLIE (17) se refere às paredes finas e permeāveis das cē lulas da extensão de bainha de feixe, como uma caracterīstica de im portância na translocação extravascular da lāmina foliar. Em s. re baudiana, a bainha dos feixes menores e suas extensões permanecem parenquimáticas, enquanto que as cēlulas que circundam os feixes das nervuras maiores sofrem esclerificação. FERREIRA (3) cita a ocorrēn cia de bainhas esclerificadas em diversas espécies de Eupatoriae.

Canais secretores esquizógenos, que se originam por divisão 
de células da endoderme, são características das compositae, poden do ocorrer em raiz, caule e folhas. Alēm de canais secretores endo dermais, tēm sido observados canais secretores em outras posiçöes nos diversos ōrgãos de determinados representantes da famîlia (15).

Nas folhas de $S$. rebaudiana, canais de secreção esquizóge nos estão opostos ao protoxilema, delimitados por células epiteliais. Foram observados canais secretores desprovidos de epitélio em cau les e rizomas de espécies de determinados gêneros de compositae, den tre eles o gênero stevia (15). De acordo com SOLEREDER (15), a posi ção dos canais secretores é uma característica útil em taxonomia de Compositae, especialmente como um caráter genērico.

AGRADECIMENTOS

Ao Professor Adelino Alvarez Filho, pela coleta de parte do material. A Senhora Antonieta Isaia da Rosa, pela confecção das lâminas permanentes.

\section{REFERENCIAS BIBLIOGRAFICAS}

1. ESAU, K. Plant anatomy. 2 ed. New York, John Wiley \& Sons, 1965, 767p.

2. FELIPPE, G.M. Stevia rebaudiana Bert.; uma revisão. Ciêneia $e$ Cultura, 29(11): 1240-8, 1977.

3. FERREIRA, A.G. Contribuição ao estudo da nervação foliar das Compositae dos cerrados. IV: Tribo Eupatoriae. Archos Bot. Es tado de são Paulo 4(3): 153-70, 1968.

4. FOSTER, A.S. Techniques for study of venation patterns in the leaves of Angiosperms. In: INTERNATIONAL CONGRESS, 7, Stockolm, 1950. Proceedings... Stockolm, 1953. 586-7.

5. HICKEY, L.J. Classification of the architecture of dicotyledo neous leaves. American Journal Botanic., 60(1): 17-33, 1973.

6. IFJU, G. Quantitative wood anatomy; a stereological approach. Blacksburg, VPI, IPT, 1977. 26 p.

7. JENSEN, W.A. Botanical histochemistry; principles and practice. San Francisco, W.H. Freeman, 1962. 408 p.

8. JOHANSEN, D.A. Plant microtechnique. New York, McGraw-Hill Book, 1940. $523 \mathrm{p}$.

9. METCALFE, C.R. \& CHALK, L. Anatomy of dicotyledons. Oxford, Cla rendon, 1950. V.2.

10. NAPP-ZINN, K. Anatomie des Blattes. I I Blattanatomie der Angios perm. In Handbuch Pflanzenanatomie. Berlin, Gebr. Borntraeger, 1973/1974. V. 8, parte 1 e 2 .

11. RAMAYYA, N. Studies on the trichomes of some Compositae. I - Ge neral structure. Bulletin Bot. Surv. India, 4(1-4): 177-88, 1962.

12. - Modes of development in the trichomes of Compositae. 
Current Science. India, 32(1): 27-8, 1963.

13. SAKAGUCHI, M. \& KAN, T. As pesquisas japonesas com stevia rebau diana (Bert.) Bertoni e o esteviosídeo. Ciência e Cultura, $34: 235-48,1982$.

14. SASS, J.E. Botanical microtechnique. 2 ed. Iowa, The Iowa State College, $1951,228 \mathrm{p}$.

15. SOLEREDER, H. Systematic anatomy of the dicotytedons. Oxford, Clarendon, 1980. 2v.

16. UPHOF, J.C. \& HUMMEL, K. Plants hairs. In Handbuch Pflanzenanatomie, Berlin, Gebr. Borntraeger, 1962. 4 t. 5.

17. WYLIE, R.B. The bundle sheat extension in leaves of dicotyledons. American Journal of Botanic, 39(9): 645-51, 1952.

Recebido em novembro, 1985; aceito em novembro, 1985. 